УдК 633.522:664.769

DOI https://doi.org/10.32851/tnv-tech.2021.5.3

\title{
ТЕХНОЛОГІЧНА СХЕМА БАГАТОЦІЛЬОВОЇ ПЕРЕРОБКИ НАСІННЯ ПРОМИСЛОВИХ КОНОПЕЛЬ
}

\author{
Петраченко Д.О. - кандидат технічних наук, \\ старший науковий співробітник відділу інженерно-технічних досліджень \\ Інституту луб'яних культур Національної академії аграрних наук України \\ ORCID ID:0000-0002-1347-9562 \\ Web of Science Researcher ID: ABC-3313-2021 \\ Коропченко С.П. - кандидат технічних наук, \\ старший науковий співробітник, \\ завідувач відділу інженерно-технічних досліджень \\ Інституту луб'яних культур Національної академії аграрних наук України \\ ORCID ID: 0000-0003-4520-4763 \\ Сова Н.A. - кандидат технічних наук, \\ доцент кафедри технології зберігання і переробки сільськогосподарської продукції \\ Дніпровського державного аграрно-економічного університету \\ ORCID ID: 0000-0003-4750-2473 \\ Web of Science Researcher ID: AAD-8848-2019 \\ Худайбердієва К.А. - асистент кафедри технології зберігання і переробки \\ сільськогосподарської продукції \\ Дніпровського державного аграрно-економічного університету \\ ORCID ID: 0000-0003-0800-6071
}

Промислові коноплі - суспільно безпечна сільськогосподарська рослина, всі частини якої знаходять використання в багатьох галузях промисловості. Для організму людини иінність представляє конопляне насіння та продукиія на його основі. Адже насіння промислових конопель є повноцінним джерелом рослинних білків, харчових волокон, низки вітамінів та мінеральних речовин, комплексом незамінних жирних кислот. Світова практика засвідчує, шо використання продукиї з насіння конопель стає пріоритетним напрямом. Виробники на постійній основі впроваджують інновачії та представляють на ринку нові продукти. Украӥнський ринок продукиії з насіння промислових конопель перебуває на етапі розвитку. Це зумовлює пошук нових нетрадиційних напрямів використання як насіння, так і супутніх продуктів його переробки.

У статті розкрито ичінність насіння промислових конопель та наведено його хімічний склад. Надано також характеристику та хімічний склад супутніх продуктів переробки насіння, таких як січка, перевій, оболонки, фільтрувальний осад, макуха. На основі иьього запропоновано комплексну техніко-технологічну схему багатоиільової переробки насіння промислових конопель. У схемі закладено послідовність дій та операцій, шо дозволяє мінімізувати відходи виробництва та підвищити ефективність переробки насіння завдяки використанню всіх отриманих продуктів. Схема передбачає одержання конопляного ядра та олії холодного пресування з подальшим використанням супутніх продуктів переробки як сировини для одержання продукиї різного призначення: технічної олії, сипких конопляних продуктів, комбікормів, кормових добавок, твердого біопалива тощяо. Впровадження розробленої схеми дозволить розиирити асортимент продукиії з насіння промислових конопель та сприятиме багатовекторному розвитку аграрних і переробних підприємств.

Ключові слова: насіння конопель, конопляна олія, конопляне ядро, переробка.

Petrachenko D.O., Koropchenko S.P., Sova N.A., Khudaiberdiieva K.A. Technological scheme of multi-purpose processing of industrial hemp seeds

Industrial hemp is a socially safe agricultural plant, all parts of which are used in many industries. Hemp seeds and products based on it are of value to the human body. After all, 
industrial hemp seeds are a full-fledged source of plant proteins, dietary fiber, and the complex of essential fatty acids, a number of vitamins, minerals. World practice shows that the use of hemp seeds is becoming a priority. Manufacturers are constantly innovating and introducing new products to the market. The Ukrainian market for industrial hemp seed products is under development. This leads to the search for new non-traditional uses of both seeds and related products of its processing.

The article describes the value of industrial hemp seeds and presents its chemical composition. The characteristics and chemical composition of related products of seed processing, such as chaff, shell, husk, filtersediment, presscake are presented. Based on this, a comprehensive technical and technological scheme of multi-purpose processing of industrial hemp seeds is proposed. The scheme includes a sequence of actions and operations that minimizes production waste and increases the efficiency of seed processing through the use of all products. The scheme provides for the production of hemp kernel and cold-pressed oil with the subsequent use of by-products of processing as raw materials to obtain products for various purposes: technical oil, bulk hemp products, compound feed, feed additives, solid biofuelsetc. The implementation of the developed scheme allows to expand the range of products from industrial hemp seeds and will promote multi-vector development of both agricultural and processing enterprises.

Key words: hemp seeds, hemp oil, hemp kernel, processing.

Постановка проблеми. Промислові коноплі - одна 3 небагатьох вітчизняних сільськогосподарських культур, всі частини якої (стебло, волокно, насіння, костриця, листя) знаходять використання в легкій, харчовій, косметичній, будівельній та інших промисловостях. Інтерес до культури збільшується у зв'язку з високою цінністю отриманих із неї продуктів [1;2]. Завдяки природному біохімічному складу конопляне насіння та продукція на його основі дедалі більше привертає до себе увагу, адже має велику цінність для організму людини [3; 4]. Тому розробка та впровадження технологій переробки насіння промислових конопель 3 метою розширення сфер його використання $є$ актуальним напрямом наукових досліджень.

Аналіз останніх досліджень і публікацій. Світова практика засвідчує, що промислові коноплі набувають статусу стратегічної культури, вирощування якої стає пріоритетним напрямом економічної політики урядів багатьох країн та інвестицій приватного бізнесу. Продукцію з насіння промислових конопель застосовують в медичній, харчовій, косметичній, паливній та інших промисловостях [5]. Виробники постійно докладають зусиль до впровадження інновацій та представлення на ринку нових продуктів із конопляного насіння. Це збільшує популярність та попит на цей вид товарів серед пересічних громадян [6; 7].

В Україні сьогодні ринок продукції, як з промислових конопель загалом, так і насіння зокрема, перебуває на етапі розвитку. Зумовлено це упередженим ставленням уряду до рослини, зарегульованістю та бар'єрами на законодавчому рівні, відсутністю сучасної бази для переробки сировини і виробництва продукції [8]. Хоча географічне положення України та науковий селекційний потенціал дає країні всі передумови, щоб стати світовим лідером промислового коноплярства [9].

Насіння промислових конопель $є$ повноцінним джерелом функціональних інгредієнтів, рослинних білків, харчових волокон, низки вітамінів та мінеральних речовин, комплексом незамінних поліненасичених жирних кислот [3; 4]. Завдяки своєму природному складу продукція на основі конопляного насіння привертає до себе дедалі більше уваги не тільки поціновувачів здорового способу життя, а й пересічних громадян, які переймаються власним здоров'ям.

Постановка завдання. Підвищений інтерес до культури промислових конопель зумовлює пошук нових нетрадиційних напрямів використання насіння i супутніх продуктів його переробки. Успішний розвиток нових напрямів гарантовано лише за умови спрощеного впровадження технологій та технічних засобів із переробки насіння в господарствах, які займаються його безпосереднім 
вирощуванням. Розробка і впровадження технологій та технічних засобів для багатоцільової переробки насіння промислових конопель сприятимуть багатовекторному розвитку аграрних і переробних підприємств.

Виклад основного матеріалу. Напрями багатоцільової переробки насіння промислових конопель повинні грунтуватися на його фізіологічних властивостях, а саме на його біологічній та поживній цінності. Згідно з результатами проведених досліджень (табл. 1) насіння промислових конопель багате на протеїн, вітаміни, мінеральні речовини, поліненасичені жирні кислоти. А враховуючи сучасний суспільний попит на якісні харчові продукти, багаті корисними мікро- та макроелементами, конопляна насіннєва продукція як один із продуктів, що покращує фізіологічні процеси в організмі людини, якраз може зайняти відповідну нішу на вітчизняному ринку.

Таблиця 1

Показники складу насіння промислових конопель

\begin{tabular}{|c|c|c|}
\hline № 3/II & Найменування & Вміст \\
\hline 1. & Масова частка клітковини, \% & 36,9 \\
\hline 2. & Масова частка протеїну, \% & 24,7 \\
\hline 3. & $\begin{array}{l}\text { Масова частка вітамінів, мг/100 г: } \\
\text { В1 } \\
\text { B2 } \\
\text { В3 (РP) } \\
\text { В9 } \\
\text { C }\end{array}$ & $\begin{array}{c}1,2 \\
0,07 \\
4,1 \\
36,1 \\
7,2\end{array}$ \\
\hline 4. & $\begin{array}{l}\text { Масова частка мінеральних речовин, г/кг: } \\
\text { Фосфор } \\
\text { Кальцій } \\
\text { Магній } \\
\text { Залізо } \\
\text { Цинк } \\
\text { Кобальт } \\
\text { Марганець }\end{array}$ & $\begin{array}{c}8,4 \\
0,8 \\
2,6 \\
87,7 \\
58,2 \\
0,5 \\
69,5\end{array}$ \\
\hline 5. & $\begin{array}{l}\text { Вміст ненасичених кислот: } \\
\text { С 18:1 олеїнова }(\omega-9) \\
\text { С 18:2 лінолева }(\omega-6) \\
\text { С 18:3 альфа-ліноленова }(\omega-3)\end{array}$ & $\begin{array}{l}16,2 \\
54,8 \\
14,8\end{array}$ \\
\hline
\end{tabular}

Аналіз світового та вітчизняного ринку коноплепродукції показує, що переробка насіння конопель базується на двох основних продуктах: олії холодного пресування та конопляному ядрі. Ці продукти є основою для виготовлення різноманітної продукції харчового, косметичного та технічного напрямів. Тому для багатоцільової переробки насіння промислових конопель першочерговим постає завдання налагодження процесу одержання конопляного ядра та пресової олії.

В Інституті луб'яних культур розроблено та відпрацьовано низку технологій, які дозволяють переробляти насіння промислових конопель за мінімізованими технологічними ланцюгами. Для задоволення потреб ринку в конопляному ядрі розроблена технологія одержання вільного від неїстівної оболонки ядра. Технологія передбачає переробку насіння конопель чистотою 95-99\% без додаткового калібрування, вологістю 6-13\% та дозволяє отримати 28-38\% готового ядра, 
засміченість якого не перевищує 1\%. Під час виробництва конопляного ядра в якості супутніх продуктів переробки одержуємо три продукти з високими поживними властивостями (табл. 2): січку (3-7\%), перевій (11-17\%) та оболонки (52-58\%).

Таблиця 2

Склад супутніх продуктів виробництва конопляного ядра

\begin{tabular}{|c|l|c|c|c|}
\hline \multirow{2}{*}{$\begin{array}{c}\text { № } \\
\text { 3/I }\end{array}$} & \multicolumn{3}{|c|}{ Воказник } & \multicolumn{3}{|c|}{ у прой речовинті в абсолютно } \\
\cline { 3 - 5 } & & Січка & Перевій & Оболонки \\
\hline 1. & Протеїн & 20,81 & 20 & 12,82 \\
\hline 2. & Жир & 32,04 & 32,85 & 19,49 \\
\hline 3. & Клітковина & 29,4 & 27,6 & 37,7 \\
\hline 4. & Зола & 6,4 & 5,62 & 4,92 \\
\hline 5. & Безазотисті екстрактивні речовини & 11,35 & 13,93 & 25,07 \\
\hline
\end{tabular}

Першим супутнім продуктом виробництва конопляного ядра є січка. Січка - це дрібно розмелене конопляне насіння, збагачене жиром $(32,04 \%)$ та клітковиною $(29,4 \%)$. До іiі складу також входить протеїн $(20,81 \%)$, безазотисті екстрактивні речовини $(11,35 \%)$ і зола $(6,4 \%)$. Враховуючи поживні властивості та структуру продукту, січка придатна для використання у технологіях виробництва харчових продуктів оздоровчого призначення, гранульованих комбікормів та кормових добавок, технічної олії.

Другим супутнім продуктом виробництва конопляного ядра є перевій. Він являє собою дрібні частки ядра та оболонок, збагачені жиром $(32,85 \%)$ і клітковиною (27,6\%). До його складу також входить протеїн (20\%), безазотисті екстрактивні речовини $(13,93 \%)$ і зола $(5,62 \%) .3$ огляду на структурні властивості та поживну цінність перевій можна використовувати для виробництва технічної олії, гранульованих комбікормів для худоби, птиці та риби.

Третім супутнім продуктом виробництва конопляного ядра $є$ оболонки. Цей вид продукту складається 3 різного розміру часток оболонки, збагачених клітковиною $(37,7 \%)$ та безазотистими екстрактивними речовинами $(25,07 \%)$. У складі продукту також присутні жир (19,49\%), протеїн (12,82\%) та зола (4,92\%). Враховуючи структурні властивості та хімічний склад, цю фракцію можна використовувати для виробництва твердого біопалива, кормових добавок, а також в якості підстилки у тваринництві.

Для одержання конопляної олії холодного пресування розроблено технологію переробки насіння за спрощеною ланкою технологічних операцій. Така технологія дозволяє переробляти конопляне насіння чистотою 97-99\%, вологістю 7-10\% та отримувати 16-22\% готової до вживання фільтрованої олії. Результати досліджень показали, що одержана конопляна олія відповідає нормативним документам та задовольняє потреби споживачів. Паралельно з олією отримуємо два супутні продукти переробки (табл. 3) з високими поживними властивостями: макуху в кількості 65-72\% та фільтрувальний осад у кількості 5-12\%.

Першим супутнім продуктом виробництва олії є макуха - знежирена білково-клітковинна сировина, яку отримують після вилучення 3 насіння олії. Цей продукт збагачений клітковиною $(35,42 \%)$ та безазотистими екстрактивними речовинами $(25,17 \%)$. У складі також присутні протеїн $(21,16 \%)$, жир $(11,57 \%)$, зола $(6,68 \%)$. Враховуючи склад макухи, подальше iї використання можливе 
у виробництві гранульованих комбікормів і кормових добавок до раціону худоби та птиці, приманок для рибальства, а також у переробці на сипкі конопляні продукти (борошно, клітковину і білкові концентрати).

Склад супутніх продуктів виробництва олії

Таблиця 3

\begin{tabular}{|c|l|c|c|}
\hline \multirow{2}{*}{$\begin{array}{c}\text { No } \\
\text { 3/II }\end{array}$} & \multicolumn{2}{|c|}{ Показник } & \multicolumn{2}{c|}{$\begin{array}{c}\text { Вміст у продукті в абсолютно } \\
\text { сухій речовині, \% }\end{array}$} \\
\cline { 3 - 4 } & & Макуха & Фільтрувальний осад \\
\hline 1. & Протеїн & 21,16 & 27,66 \\
\hline 2. & Жир & 11,57 & 55,84 \\
\hline 3. & Клітковина & 35,42 & 3,77 \\
\hline 4. & Зола & 6,68 & 6,81 \\
\hline 5. & Безазотисті екстрактивні речовини & 25,17 & 5,92 \\
\hline
\end{tabular}

Другим супутнім продуктом виробництва олії є фільтрувальний осад - осад, який виділяється 3 олії під час ії фільтрування і складається з фосфатидів, олії, вологи та жирових домішок. Фільтрувальний осад збагачений жиром $(55,84 \%)$ і протеїном (27,66\%). У складі також присутні незначні частки золи $(6,11 \%)$, безазотистих екстрактивних речовин $(5,31 \%)$, клітковини $(3,38 \%)$. Враховуючи склад продукту та його структурні властивості, подальше використання фільтрувального осаду доцільне у виробництві кондитерських виробів, кормових добавок для худоби та птиці, косметичних засобів по догляду за шкірою або як основи у виготовленні продукції енергетичного спрямування.

Проведені дослідження дозволили об'єднати окремі технологічні ланцюги та операції, що лягло в основу розробки техніко-технологічної схеми багатоцільової переробки насіння промислових конопель (див. рис. 1). Завдяки комплексному підходу, врахуванню поживних і структурних властивостей ця схема дозволяє залучити у виробництво всі супутні продукти переробки конопляного насіння, що значно підвищує ефективність процесу. Схема багатоцільової переробки конопляного насіння базується на виробництві двох основних продуктів: конопляного ядра та олії холодного пресування. Вона поєднує в собі технології виробництва конопляного ядра, харчової або технічної олії, сипких конопляних продуктів, гранульованих комбікормів та твердого біопалива. Виходячи з кінцевої мети переробки та наявної кількості необхідної сировини, технологічні ланцюги можуть виконуватися послідовно, а також паралельно.

В основу виробництва конопляного ядра покладено використання механічного обрушування насіння та повітряно-решітної сепарації. У процесі переробки технологія обрушування насіння передбачає одержання фракції необрушеного насіння - так званого продукту повторної обробки. Цю фракцію використовують для повторного обрушування, що є доцільним для отримання максимального відсотка конопляного ядра або харчової олії, якщо, окрім конопляного ядра, на меті $\epsilon$ одержання олії. Важливо пам'ятати, що для отримання харчової олії високої якості ці технологічні ланцюги повинні відбуватися послідовно в один день. Адже конопляне насіння за своєю природою схильне до швидкого окиснення, що погіршує його якість та властивості.

Отримані в процесі обрушування супутні продукти: перевій і січку, можна використовувати для виробництва технічної олії за технологічною схемою одержання 
олії, де виконуються операції холодного пресування та фільтрування. Інший напрям використання - це виробництво гранульованих комбікормів, під час якого виконуються технологічні операції подрібнення, просіювання та гранулювання. Отримані в процесі обрушування оболонки без додаткової обробки придатні для використання на енергетичні цілі. Однак у натуральному вигляді транспортувати та використовувати оболонки незручно. Тому рекомендуємо виготовляти з них тверде біопаливо за допомогою подрібнення та пресування в паливні брикети.

Для виробництва конопляної олії можна використовувати технологію холодного пресування, яка передбачає операції вилучення олії за допомогою пресування матеріалу та фільтрування. Згідно з технологією для пресування використовують шнековий одноступінчатий прес, а для фільтрації - безвакуумний фільтрувальний мішок або фільтрувальну лінію. Отриману в процесі виробництва макуху спрямовують для виготовлення сипких конопляних продуктів. Для цього виконують операції механічного подрібнення та просіювання, що дозволяє одержати три готові продукти: клітковину, борошно та білковий концентрат. Інший напрям

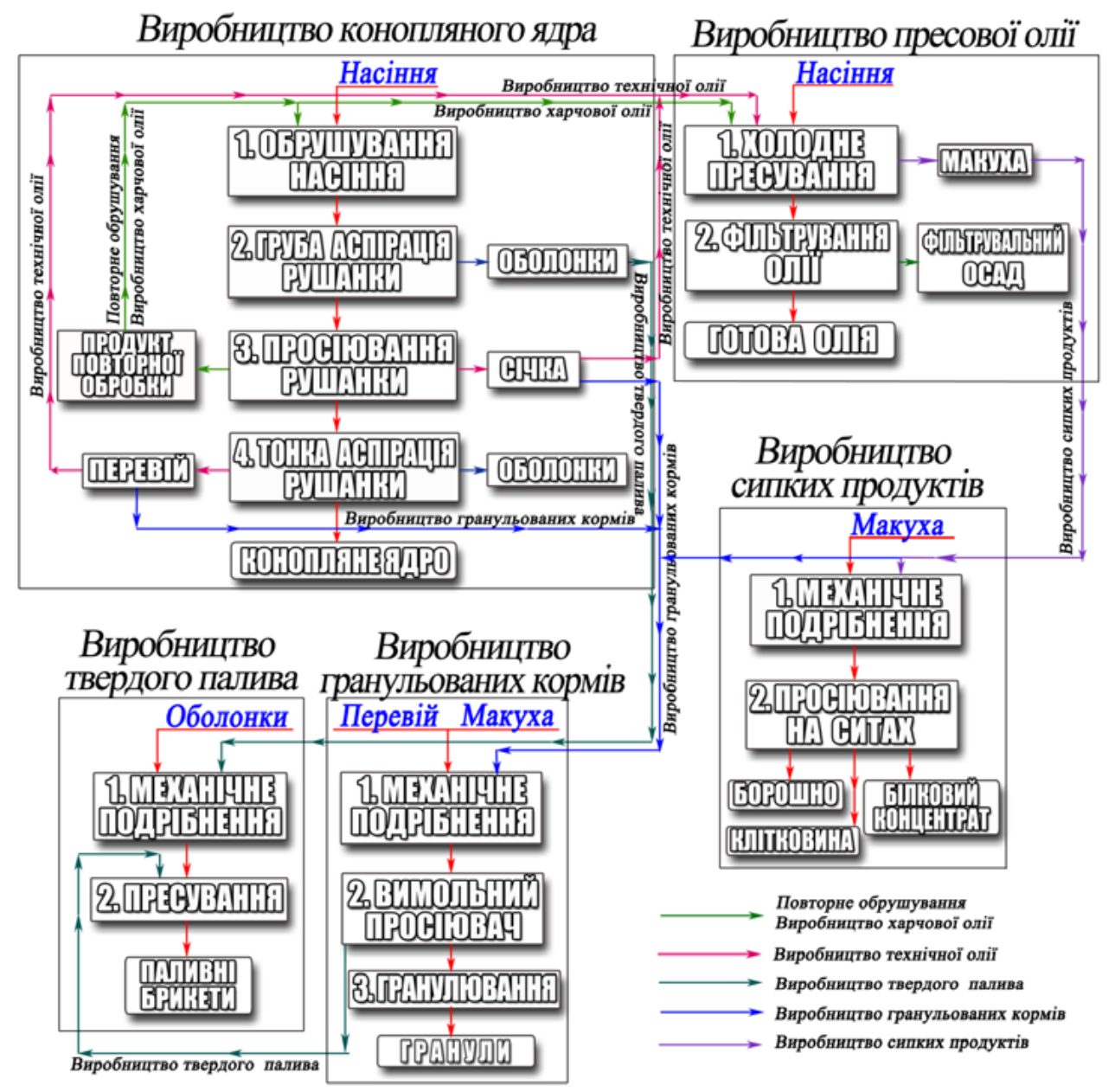

Рис. 1. Схема багаточільової переробки насіння промислових конопель 
використання - це виготовлення гранульованих кормів, де виконують операції подрібнення, просіювання та гранулювання. Отриманий у процесі виробництва олії фільтрувальний осад використовують в натуральному вигляді як біологічно цінну харчову, кормову добавку або на енергетичні цілі.

Висновки. Розроблена технологічна схема багатоцільової переробки насіння промислових конопель дозволяє залучити у виробництво всі частини насіння та супутні продукти його переробки. Впровадження технологічної схеми дає змогу одержати нову продукцію та розширити сфери використання складників насіння. Реалізація цієї схеми безпосередньо у господарствах, що культивують коноплі, дозволить підвищити ефективність вирощування конопель та збільшити економічний ефект.

\section{СПИСОК ВИКОРИСТАНОӤ ЛІТЕРАТУРИ:}

1. Ляліна Н.П. Світовий та вітчизняний досвід використання конопель для виготовлення товарів широкого вжитку. Вісник Херсонського національного технічного університету. 2014. № 2. С. 86-90.

2. Примаков О.А. Ненаркотичні коноплі: перспективи застосування. Аграрний тиждень. URL: http://a7d.com.ua/plants/14427-nenarkotichn-konopl-perspektivizastosuvannya.html (дата звернення: 29.10.2021).

3. Hemp seed as a nutritional resource: An overview. URL: http://link.springer.com/ article/10.1007/s10681-004-4811-6 (дата звернення: 29.10.2021).

4. 7 proven benefits of hemp seed. URL: https://www.organicfacts.net/hemp-seeds. html (дата звернення: 29.10.2021).

5. Мировой рынок конопли посевной. URL: http://konoplex.ru/zarubezhnyj-opyt/ (дата звернення: 29.10.2021).

6. Состояние и перспективы мирового коноплеводства. Европа. URL: https://www.rosflaxhemp.ru/zhurnal/informacija-i-analiz.html/id/2003 (дата звернення: 29.10.2021).

7. Hemp seeds market size, share \& COVID-19 impact analysis, by form (whole hemp seed, hulled hemp seed, hemp seed oil, and hemp protein powder), application (food \& beverage, personal care products, industrial products, and others), and regional forecast, 2020-2027. URL: https://www.fortunebusinessinsights.com/toc/hemp-seedsmarket-103478 (дата звернення: 29.10.2021).

8. Зелена книга. Ринок технічних конопель. URL: https://cdn.regulation. gov.ua/59/54/a3/1e/regulation.gov.ua_Green\%20Book_More\%20transparent $\% 20$ regulation $\% 20 \mathrm{of} \% 20 \mathrm{industrial} \% 20 \mathrm{hemp} \% 20 \mathrm{in} \% 20 \mathrm{Ukraine}$.pdf (дата звернення: 29.10.2021).

9. Коноплярство: наукові здобутки і перспективи : монографія / В.Г. Вировець та ін. Суми : ФОП Щербина I.В., 2018. 158 с.

\section{REFERENCES:}

1. Ljalina, N.P. (2014) Svitovyi ta vitchyznianyi dosvid vykorystannia konopel dlia vyhotovlennia tovariv shyrokoho vzhytku [World and domestic experience in the use of hemp for the manufacture of consumer goods]. Visnyk Hersons 'kogo nacionalnogo tehnichnogo universytetu. № 2. P. 86-90. [in Ukrainian]

2. Prymakov, O.A. (2013) Nenarkotychni konopli: perspektyvy zastosuvannja [Non-narcotic hemp: prospects for use]. Agrarnyj tyzhden'. Retrieved from: http:// a7d.com.ua/plants/14427-nenarkotichn-konopl-perspektivi-zastosuvannya.html. [in Ukrainian]

3. Hemp seed as a nutritional resource: An overview. Retrieved from: http://link.springer.com/article/10.1007/s10681-004-4811-6.

4. 7 proven benefits of hemp seed. Retrieved from: https://www.organicfacts.net/ hemp-seeds.html. 
5. Mirovoj rynok konopli posevnoj [The world market for sowing hemp]. Retrieved from: http://konoplex.ru/zarubezhnyj-opyt/. [in Russian]

6. Sostoyanie i perspektivy mirovogo konoplevodstva. Evropa [The state and prospects of world hemp growing. Europe]. Retrieved from: https://www.rosflaxhemp.ru/ zhurnal/informacija-i-analiz.html/id/2003. [in Russian]

7. Hemp seeds market size, share \& COVID-19 impact analysis, by form (whole hemp seed, hulled hemp seed, hemp seed oil, and hemp protein powder), application (food \& beverage, personal care products, industrial products, and others), and regional forecast, 2020-2027. Retrieved from: https://www.fortunebusinessinsights.com/toc/ hemp-seeds-market-103478.

8. Zelena knyha. Rynok tekhnichnykh konopel [Green Paper. Technical hemp market]. Retrieved from: https://cdn.regulation.gov.ua/59/54/a3/1e/regulation.gov.ua Green\%20Book_More\%20transparent\%20regulation $\% 20$ of $\% 20$ industrial $\% 2 \overline{0}$ hemp \%20in\%20Ukraine.pdf. [in Ukrainian]

9. Vyrovec, V.G., Lajko, I.M., Mygal', M.D., Dudukova, S.V., Zhuplatova, L.M., Kyrychenko, G.I. et al. (2018) Konopliarstvo: naukovi zdobutky i perspektyvy : monohrafiia [Hemp growing: scientific achievements and prospects: monograph]. Sumy : FOP Shherbyna I.V. [in Ukrainian] 